\title{
Lithostratigraphy of Tabul Formation and Onshore Geology of Nunukan Island, North Kalimantan
}

\author{
Salahuddin Husein* \\ Department of Geological Engineering, Faculty of Engineering, Gadjah Mada University, Yogyakarta, Indonesia
}

\begin{abstract}
Nunukan Island is located in Northeast Kalimantan Basin, one of prolific basin in western Indonesia. However, this island lies in northern verge of the basin and hydrocarbon exploration were limited before the 1940s. No detail geological fieldworks has been published. This paper attempts to share geological information obtained from few accessible outcrops, particularly from the western part of the island where previous oil drilling were carried out. Most of the island have been built by Tabul Formation, which was also the main objective of reservoir for hydrocarbon exploration. It is composed of claystones, siltstones, and sandstones interbeds, deposited in transitional environment during Late Miocene. They exhibit coarsening upward sequence, the lower part composed of heterolitic sandstones deposited in tidal flats, and the upper part composed of arkosic sandstones deposited in distributary channels and mouthbars. The eastern coastal strip was constructed by Tarakan conglomerates, which have been deposited in fluvio-deltaic environment in Pliocene, unconformably over the Tabul clastics. Those Neogene deposition of paleo-Simengaris Delta apparently deformed and inverted in Plio-Pleistocene, contemporaneously with basaltic volcanism which spread widely over northeastern Borneo, which also observed in the northern half of the Nunukan Island.
\end{abstract}

Keywords: Lithostratigraphy · Tabul Formation · Onshore geology · Hydrocarbon exploration $\cdot$ Nunukan Island $\cdot$ Kalimantan.

\section{INTRODUCTION}

The Tabul Formation is one of main reservoir in Tarakan Basin, northeastern perimeter Kalimantan. Their productive sand were proven during exploration in Bunyu Island, particularly in Tapa and Nibung fields, as well as in Sembakung Field in the mainland of North Kalimantan. However, this formation is not exposed in Bunyu Island, thus they were studied exstensively in wells and subsurface logs. Instead, the Tabul Formation cropped considerably out on Nunukan Island, located $45 \mathrm{~km}$ in NNW direction from Bunyu Island (Figure 1). Yet only few attention have been paid to their occurrence on the Nunukan Island, and not any particular publication ever mentioned

\footnotetext{
${ }^{*}$ Corresponding author: S. HUSEIN, Department of Geological Engineering, Gadjah Mada University. Jl. Grafika 2 Yogyakarta, Indonesia. E-mail: shddin@ugm.ac.id
}

field study of the formation to date. This paper goes to presence field sedimentological observation of Tabul Formation onshore of Nunukan Island, which considering regional tectonic history and erosional intensity could be deliberately regarded as lower part of the formation. Along with field observation upon other rock formation in the island, a geologic synthesis is proposed, as an effort to elucidate geological history of the island.

\section{Geological Setting}

\section{A. Tarakan Basin and Tidung sub-basin}

The Tarakan Basin, in factual, is a shared name applied to four sub-basins located in the northeast peripheral of Kalimantan. They consist of Tarakan sub-basin in the centre offshore, Muara sub-basin in the southeast offshore, Berau subbasin in the southwest onshore, and Tidung sub-basin in the northwest onshore (Figure 1). 
The Tarakan Basin is bounded to the north by Semporna Peninsula, to the west by SekatakBerau Ridge (which is part of Kuching High), to the south by Mangkalihat Peninsula, and to the east by deepwater of Sulawesi Sea (Achmad and Samuel, 1984).

Tectonically, the Tarakan Basin is bounded by two major NW-SE strike-slip sinistral faults, the Semporna Fault in northern margin and Mangkalihat Fault in the southern margin (Lentini and Darman, 1996). These strike-slip faults were interpreted to be responsible for several sub-parallel isoclinal arch structures in the Tarakan sub-basin, they are Tarakan Arch $( \pm 100 \mathrm{~km}$ length), Bunyu Arch $( \pm 40 \mathrm{~km}$ length) and Ahus Arch ( $\pm 30 \mathrm{~km}$ length). The Tarakan and Bunyu arches host $92 \%$ of all commercial hydrocarbon accumulations in the basin, and their plunging noses have been the target most of the offshore exploration effort (Wight et al., 1993). Nunukan Island itself is considered as northwest extension of Ahus Arch, separated by a small, intervening Pleistocene trough underlain by Pliocene below an angular unconformity, attesting to a major post-Pliocene orogeny. As located closer to the bounding fault of Semporna Fault, Tidung subbasin was considered to be highly deformed, as Mio-Pliocene sequences were intensively eroded, widely exposing the Tabul Formation (Rosary et al., 2014).

Achmad and Samuel (1984) divided the northern Tarakan sub-basins (Tidung and Tarakan) stratigraphy into 5 depositional cycles, intimately dictated by interplay between Kuching High episodic uplift as the clastic provenance and the regional eustasy. The first cycle was starting from regional transgression in the Late Eocene to Late Oligocene during deposition of Sujau clastics, Seilor carbonates, and Mangkabua marls. The second cycle took place during latest Oligocene to early Middle Miocene, where Tempilan clastics interfingered with Tabalar limestones and overlaid by Naintupo shales. The third cycle occurred during Middle to Late Miocene, marked by tremendous supply of Meliat deltaic sediments followed by regressive clastics of Tabul and Santul. The fourth cycle was deposited during Pliocene by the occurrence of Tarakan deltaic sequences. The fifth cycle occured from early to late Pleistocene by deposition of Bunyu deltaic succession during the on going sea-level rise.

\section{B. Tabul Formation}

The name Tabul was used by Dutch geologists for the Middle to Late Miocene prograding deltaic sequences found in north Tidung subbasin outcrops. They consists of sandstones, siltstones, claystones interbeds. Its type locality is located in Tabul River, Simengaris Estuarine, where they were gently-dipping exposed for $\sim 5 \mathrm{~km}$ length (Hidayat et al., 1995). However, they were noted to be widely exposed and accessible in Nunukan Island. Wight et al. (1993) considered that Tidung Formation were deposited as initial sequences of Mio-Pliocene Simengaris Delta.

In Mandul Island, adjacent to Bunyu Island, this formation exposes and reached $1500 \mathrm{~m}$ thick, and tends to increase in thickness eastward (Achmad and Samuel, 1984). Akuanbatin et al. (1984) reported the Tabul Formation reached $2000 \mathrm{~m}$ thickness subsurface in Bunyu Island, which was interpreted to be deposited in delta front to prodelta environment, with some limestone stringers observed as an indication of marine transgression. In wells, they have coarsening upward characteristics, typical for prograding delta. Claystones range from 5 to $20 \mathrm{~m}$ in thickness, whilst sandstones is finegrained and rarely reached $10 \mathrm{~m}$ thickness.

\section{Hydrocarbon occurences and exploration}

It has been reported that two wells were drilled onshore Nunukan in 1939 (NNK-1) and 1942 (NNK-2) with hydrocarbon shows but further exploration was interrupted by World War II (Rosary et al., 2014). They were located on anticlinal crest in the western coast of island. Gas can still be found escaping from around wellhead. Afterward, exploration focus has been concentrated in Tarakan sub-basin, particularly in the islands of Tarakan and Bunyu.

The target reservoir in Nunukan Island was the Tabul Formation, as have been proved to be producing in the Sembakung Field. It comprises a series of interbedded claystones, mudstones, sandstones and limestones, with thickness ranges reached $900 \mathrm{~m}$, and porosities averaging around $20 \%$ (Rosary et al., 2014). Other Tabul reservoirs in Bunyu Island are known at greater depths (2500 to $3500 \mathrm{~m}$ ), within the dis- 


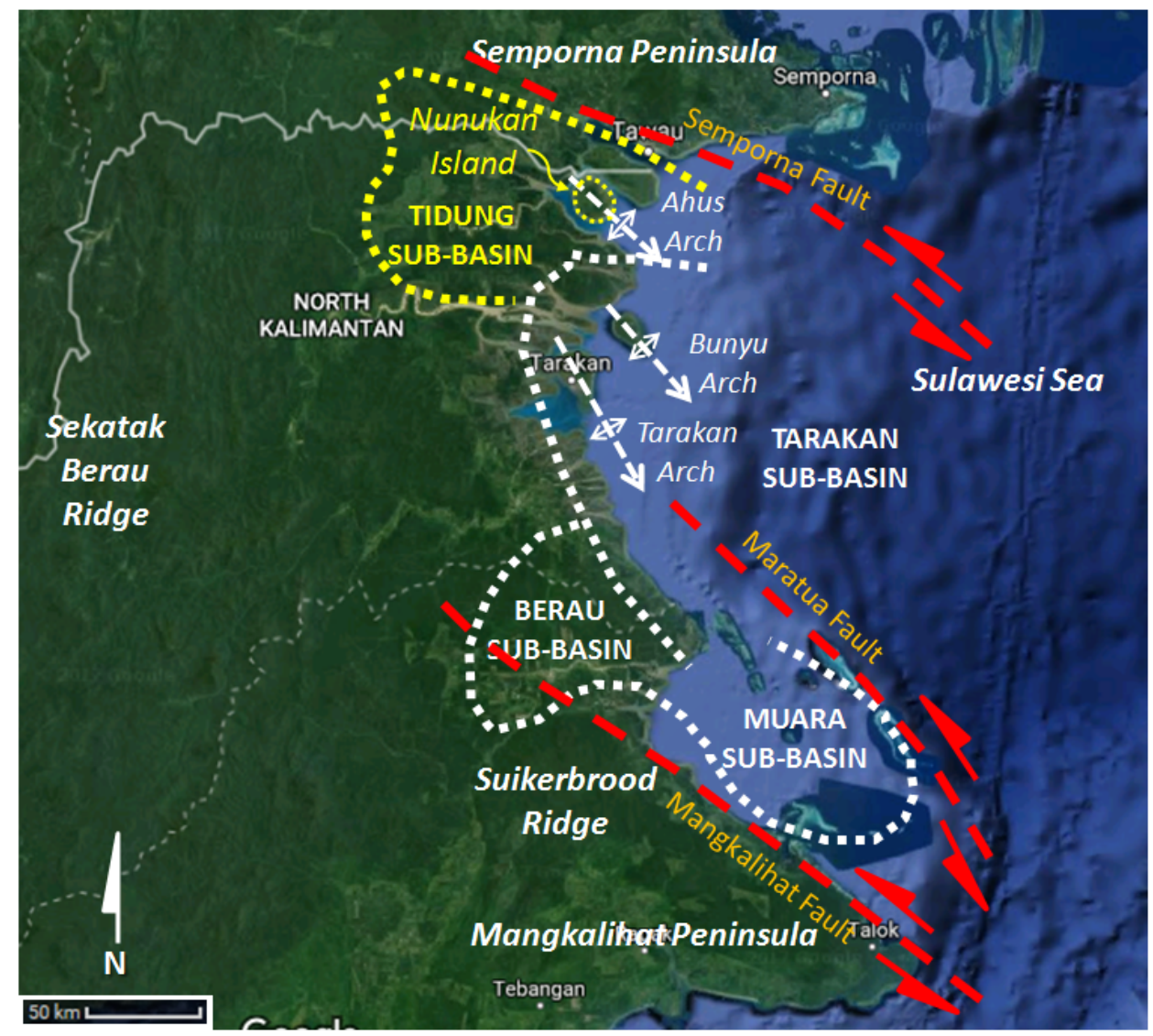

Figure 1: Regional setting of Nunukan Island and Tidung sub-basin (image from GoogleEarth).

tal delta front and prodelta section (Akuanbatin et al., 1984). Interbedded shales provide good vertical seals.

The primary source rocks are moderately organic-rich shales and coals of the Middle Miocene Meliat Formation and the Late Miocene Tabul Formation when depth of burial has been sufficient (Rosary et al., 2014). They were deposited in lacustrine, coastal plain and deltaic environments, and the organic matter is typically kerogen Type III of terrestrial origin. The kitchen area of the Tidung sub-basin is concentrated in the SembakungBangkudulis graben. Intense oil generation was thought have been occurred since 3 Mya (Lower Pliocene) which were fully mature (Ro $>0.7$ ) at 3200 to $3900 \mathrm{~m}$ depth (Rosary et al., 2014).

\section{DATA AND Methods}

This paper is developed from geological field observation, where sedimentologic and stratigraphic data were obtained from 7 (seven) outcrops (Figure 2). Stratigraphic measured section was conducted in each outcrop, with a scale of 1:100. Detail examination on sedimentary textures and structures, as well as paleontological evidences, were done on site. Geometry and relationtship between each sedimentary bodies were also carefully noted.

Selection of outcrops considered the structural condition of Nunukan Island. Tabul clastics covers $3 / 4$ of the island surface, and only in the eastern coastal strip they were covered by Tarakan conglomerates. Most of the outcrops dip to northeast, thus field survey was conducted from north part of island where the youngest section was located, to southwestern coast near the Nunukan-2 Well where the oldest section was placed.

\section{Results AND Discussion}

\section{A. Field sedimentological observation}

Presentation of observation result is following depositional succession, from the oldest to the youngest. Lithofacies description are given and followed by their interpretative depositional environment.

a. Outcrop NN.18 - Binusan (E 570212 $\mathrm{N} 443618$ ): this $7.25 \mathrm{~m}$ thick outcrop nearby 


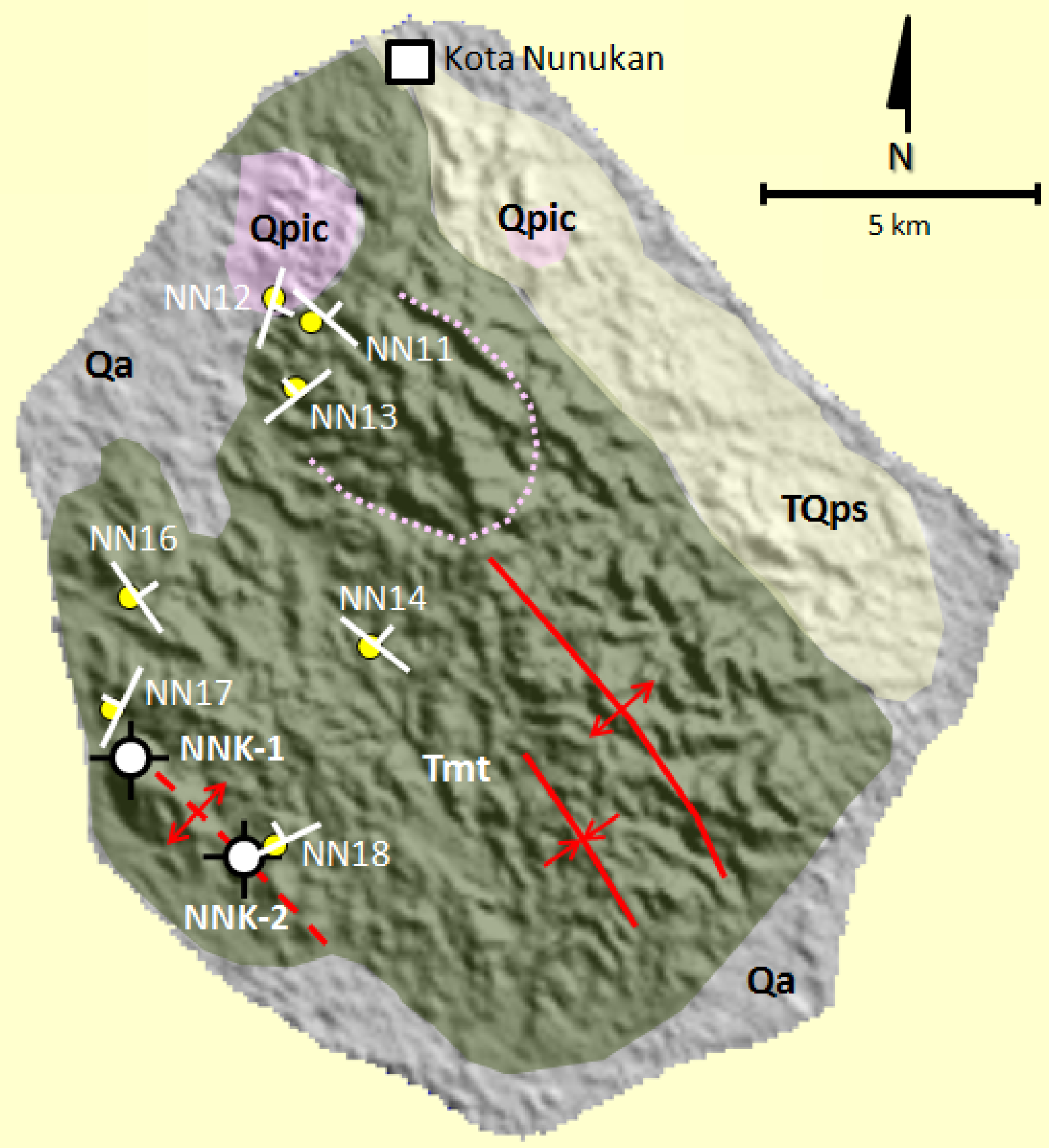

Figure 2: Outcrop distribution (yellow circles) onshore of Nunukan Island plotted on geological map, superimposed on SRTM-DEM imagery. Green polygon is surface distribution of Tabul Formation (Tmt), pale-yellow polygon is Tarakan Formation (TQps), pink polygons are basalt (Qpic), and grey polygons are alluvium (Qa). Pink dashed-line is inferred occurrence of basaltic volcano, mostly subcropped underneath Tabul clastics. Red arrows indicate axial line of Nunukan folds (Netherwood and Wight, 1992; Hidayat et al., 1995). Location of two existing wells are indicated. 
NNK-2 well is composed of heterolithic sandstones with current ripples, intercalated by shales which exhibit wavy ripples. Lateral accretions were plainly observed in sandstones (Figure 3a). Bioturbation was less intense, planolites only occurred in sandstones (Figure $3 b$ ). This outcrop is interpreted to be deposited in tidal flats, where sand flat recurrently covered by mud flat, suggesting few regressive breaks took place in esturine environment.

b. Outcrop NN.17 - Binusan (E 567304 $\mathrm{N} 446026)$; this $6.5 \mathrm{~m}$ thick outcrop nearby NNK-1 well is composed of heterolithic sandstones, intercalated by shales. Sandstones are characterized by bidirectional current ripples, whilst the overlying shales exhibit wavy ripples. The lower part consists of lenticular shales, gradually coarsening and thickening upward, to be dominated by fine-grained sandstones, which later gradually fining and thinning upward become lenticular shales. They are interpreted to be deposited in tidal flats, where sand flat were packed in between mud flats, suggesting transgressive break in estuarine environment.

c. Outcrop NN.16 - Binusan (E 567583 $\mathrm{N} 448071$ ); this $3 \mathrm{~m}$ thick outcrop is composed of fine-grained heterolithic sandstones, intercalated by shales in flaser lamination. Both are having sharp contact, with sandstone surface exhibits current ripples. Sandstones were deposited in tidal channel environment, as indicated by channel fill, lateral accretion (Figure 4b), channel structures (Figure $4 \mathrm{a}$ ), and coarsening upward succession. Bioturbation were rare, mostly sub-horizontal of Planolites ichnofacies.

d. Outcrop NN.14 - Binusan (E 571941 $\mathrm{N} 447189$ ); this $12 \mathrm{~m}$ thick outcrop is constructed by two contrasting sedimentary facies. The lower part is composed grey shales, characterized by lenticular lamination, and interpreted to be deposited in prodelta environment. They are intercalated by fine-grained sandstones, exhibit current ripples, and oxidized at the surface. A handful horizontal bioturbation were observed, mostly belong to Cruziana ichnofacies (Figure 5b). The upper part of outcrop is constructed by arkosic sandstones, whitish yellow in appearance. They were deposited in low-angle trough cross-lamination structures, with organic material sheets covered the trough surface. These sandstones is interpreted to be deposited in distributary channels, as palpable lateral accretion, channel structures, and channel-bank collapse (Figure 5a) were observed.

e. Outcrop NN.13 - Binusan (E 570515 $\mathrm{N} 451780$ ); this $6.5 \mathrm{~m}$ thick outcrop is located in Binusan City Forest, exposing a massive arkosic sandstones, pale yellow, with low-angle trough cross-bedded, and interpreted to be deposited in distributary channel environment.

f. Outcrop NN.12 - Binusan (E 570182 $\mathrm{N}$ 453434); this $20 \mathrm{~m}$ thick outcrop behind the military base of Kodim 0911/Nunukan (Figure 6), exposing arkosic sandstones, pale yellow, well-sorted, low-angle trough cross-bedded with lingoid current ripples at their surface (Figure $7 b$ ), intermittenly covered by clay-drapes and carbon flakes. Bedding surface often covered by hematite, which also frequently presents as iron nodule of various size. Liesegang structures gave reddish hue on the outcrop surface. This sandstone is interpreted to be deposited in distributary channel environment. The upper part overlied by $1 \mathrm{~m}$ thick shales, dominated by lenticular structures with convolute in the basal part (Figure 7a) and capped by lignite, possibly deposited in crevasse splays. The lower section of outcrop was intruded by basalts (Figure 7c), with plagioclase phenocryst embedded in mafic groundmass. Their baking contact to sandstones altered the latter into kaolinite. Those Tabul clastics were cut by a ENE-WSW sinistral fault, dragged lignite layer into vertical dipping within its shear zone, suggesting a working NE-SW compressional stress (Figure 6). A sub-parallel normal fault is also present accompanying the strike-slip fault, suggesting a NW-SE extensional stress, possibly working as releasing phase after the compressional one.

g. Outcrop NN.11 - Binusan (E 570793 
- N 453042); this $15 \mathrm{~m}$ thick outcrop of arkosic sandstones containing wellrounded lithic fragments, pale yellow, low-angle trough cross bedded (Figure 8b) covered by clay drapes. Hematite layers occur in between bedding, often appear as iron nodules. Diagenetic structure of liesegang gave reddish hue on outcrop surface. These sandstones are interpreted to be deposited in distributary channels. The lower part of outcrop exposes grey shales, rich in carbon-flakes (organic materials), with few horizontal bioturbation (Figure $8 \mathrm{c})$, possibly have been deposited in interdistributary bay deposits. The sandstones intruded by basalts, possibly in shallow depth, as the appearance of columnar joints dominating the igneous rock body. The basalts exhibits plagioclase phenocryst embedded in mafic ground mass.

\section{B. Lithostratigraphy of Tabul Formation on Nunukan Island}

Distribution of observed lithologies are generally dipping to northeast. A provisional geologic section for the western part of Nunukan Island was constructed in NE-SW direction, showing two main lithofacies of Tabul Formation, intruded by one igneous rock unit (Figure 9). The first unit, building the southwestern part of island, is composed of heterolithic sandstones which frequently intercalated by thick shales. The second unit, assembling the central part of island, is composed by arkosic sandstones, occasionally intercalated with thin shales. This latter rock unit was intruded by basalt.

The heterolithic sandstones, coarsening upward, mostly occupied by current ripples, occasionally herringbone structures were observed, and lateral accretion were clearly noticed. Organic materials were abundant, entraped as carbon flakes deposited inside ripple troughs. Bioturbation were less intense, mostly dominated by Cruziana ichnofacies, indicating a low energy environment. These heterolithic sandstones are interpreted to be deposited in tidal flats within an estuarine environment, the lower part probably occurred during last stage of highstand sytem tract, whislt the upper part

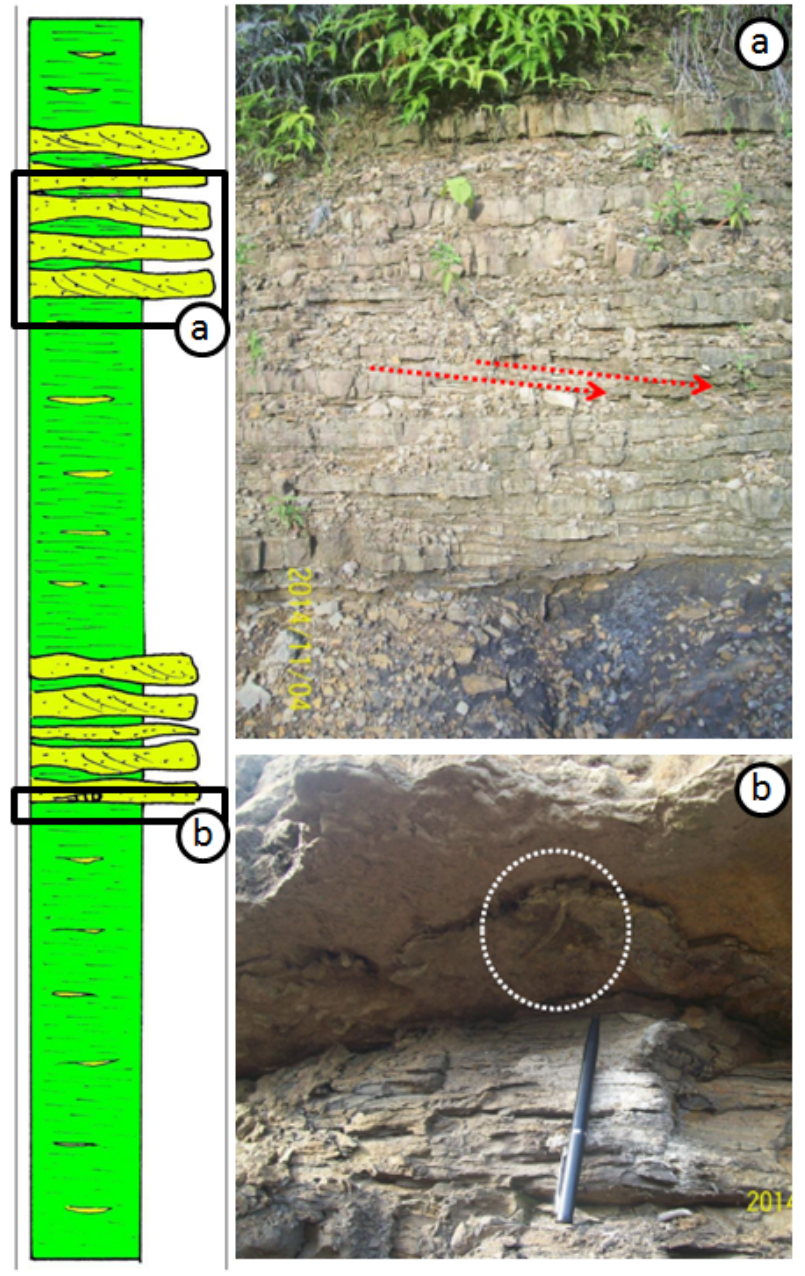

Figure 3: (a) Heterolithic sandstones dominated by current ripples, with noticeable lateral accretion (indicated by red arrows). (b) Heterolithic sandstones overlying organic-rich shales. Both are having sharp contact, and lateral bioturbation of Planolites ichnofacies were observed at the bottom of sandstones (indicated by whitedashed circle).

took place during the initial phase of falling stage sytem tract (Shanley and McCabe, 1984).

The arkosic sandstones, mostly composed of fine to medium grained quartz grains, with abundant well-rounded lithic fragments, deposited by low-angle trough cross beds within lateral accretion packages, abut to channel structures. Clay drapes frequently cover bedding surface, incorporating carbon flakes. These amalgamated channel sandstones are interpreted to be deposited in distributary channels of upper delta plain. Intermittenly they are interupted by shales and lignite, those deposited in crevasse splays and flood plains. 


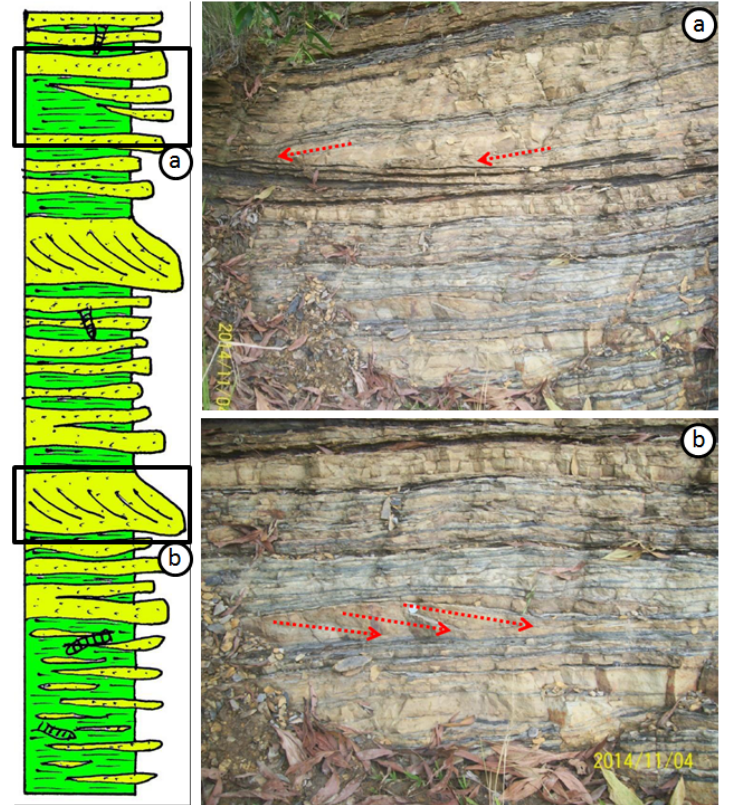

Figure 4: (a) Channel-fill by flaser-laminated heterolithic sandstones, onlapped over channel bank (indicated by red arrows). Shale thickness varies, controlled by weight-loading of channel fills. (b) Lateral accretion (indicated by red arrows) as indication of channel migration, are well developed in flaser-laminated heterolithic sandstones.

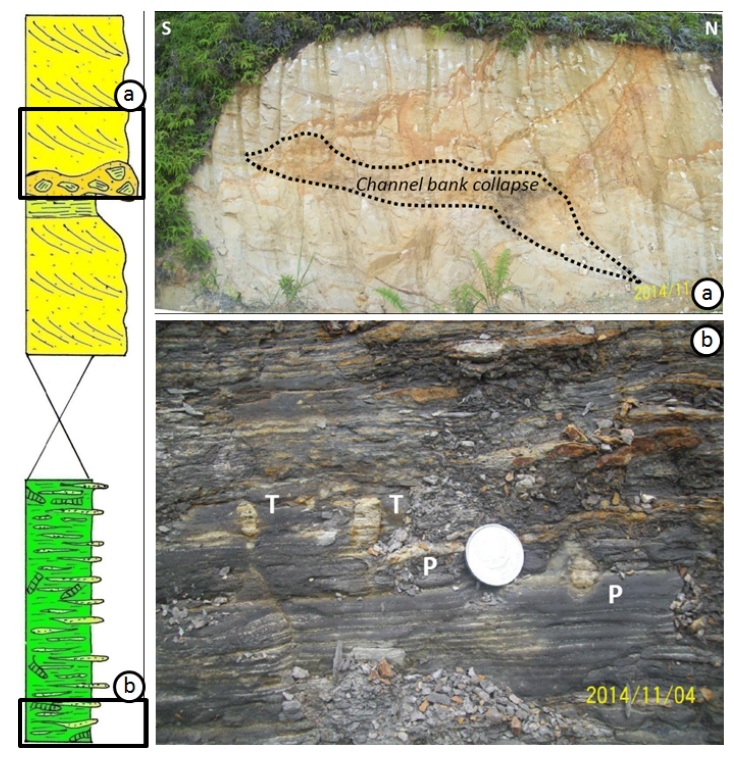

Figure 5: (a) Arkosic sandstones, with channelbank collapse, those composed of shale fragments. Lateral accretion suggests channel migration to the north. (b) Grey shales interrupted by lateral bioturbation, mostly in $1 \mathrm{~cm}$ width, of Teichichnus $(\mathrm{T})$ dan Planolites $(\mathrm{P})$ species those belong to Cruziana ichnofacies.
This succession was possibly deposited during the initial phase of lowstand system tract (Shanley and McCabe, 1984).

Wight et al. (1992) proposed that the deposition in Tidung sub-basin and the northern part of Tarakan sub-basin were carried out by paleo-Simengaris Delta. Thus the above mentioned facies changing of Tabul Formation on Nunukan Island reflects a dynamic interplay between two major factors: the amount if silisiclastics sediments supplied by hinterland through Simengaris River and the eustatic response of the basin. The former factor in turn was defined by the rate of on-going regional tectonic uplift in Kuching High and river-channel switching, while the latter factor defined by the rate of basin subsidence and regional sea-level fluctuation. For those reasons, a hiatus was noticed to be occurred between the heterolithic sandstones unit and the arkosic sandstones, as they have a lacuna in their sequential tracts, which were from initial phase of falling stage to initial phase of lowstand system.

\section{Onshore geology of Nunukan Island}

The Nunukan Island is mainly built by silisiclastic sequences of Tabul Formation, as they are the oldest rock succession and occupied more $60 \%$ of island surface. They are then unconformably overlaid by the Pliocene Tarakan conglomerates, during the subsequent paleo-Simengaris Delta progradation. Those Tarakan conglomerates barely occupy the eastern coastal strip, suggesting a substantial erosion occurred on Nunukan Island after the deposition of Tarakan Formation, as have been pointed out in other part of Tarakan Basin by existing seismic data (Akuanbatin et al., 1984; Wight et al., 1992; Noon et al., 2003; Rosary et al., 2014).

The responsible tectonic inversion was taken place in Plio-Pleistocene, corresponding with the formation of Tarakan arches, including Ahus Arch in Tidung sub-basin (Akuanbatin et al., 1984; Wight et al., 1992; Lentini and Darman, 1996; Noon et al., 2003; Rosary et al., 2014). Vitrinite reflectance, porosity and seismic data suggest $1000-1500 \mathrm{~m}$ of structural inversion occurred during arch formation (Lentini and Darman, 1996). Hitherto two mechanism for arch formation have been proposed. Most of geoscientists working in Tarakan Basin agreed 


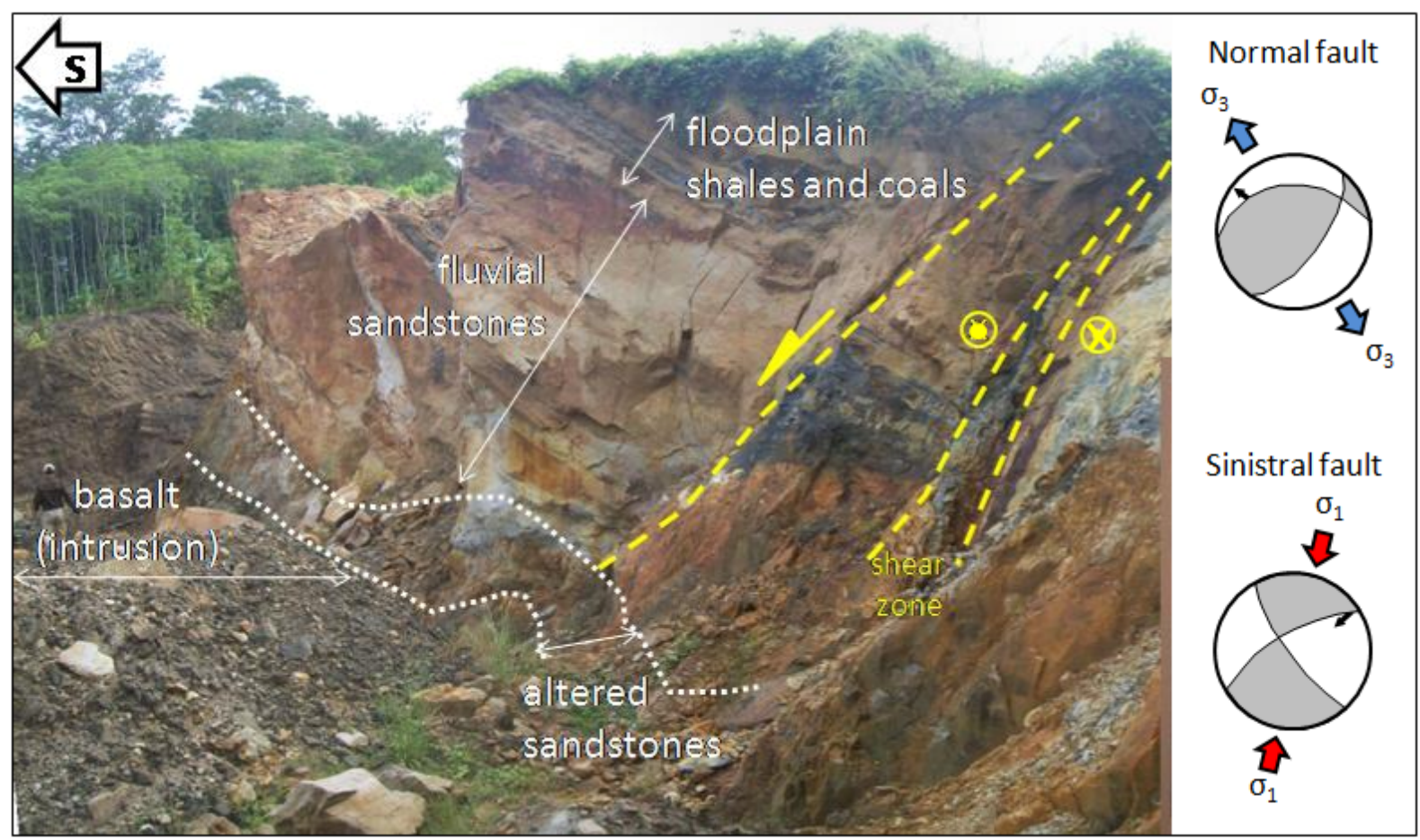

Figure 6: A $20 \mathrm{~m}$ thick outcrop of Tabul sandstones, intruded by basalt. Two local faults were recognized and kinematically interpreted to be related with regional tectonic framework.

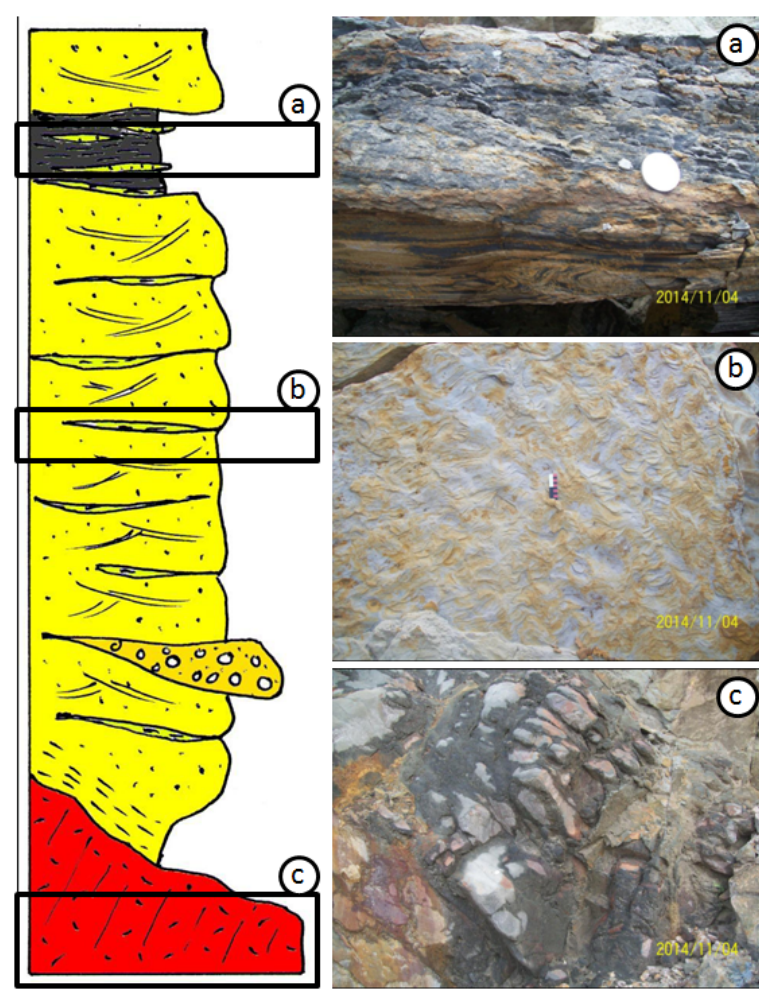

Figure 7: (a) Dark-grey shales, organic-rich, with basal convolute structures. (b) Lingoid current ripple marks on sandstone bedding surface, indicating high energy environment. (c) Basalt, grey and weathered.
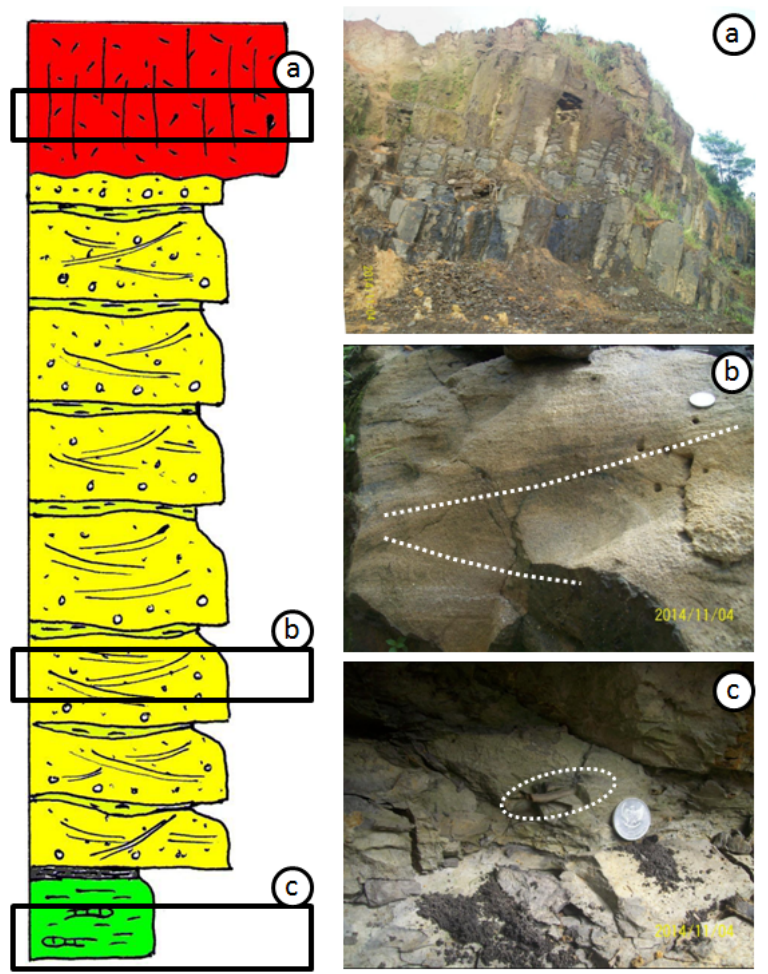

Figure 8: (a) Columnar joint structures in basalt. (b) Arkosic sandstones with well-rounded lithic fragments in low-angle trough cross-bedded. (c) Light-grey shales, rich in organic materials (carbon flakes), with few horizontal biotrubation of Planolites ichnospecies 


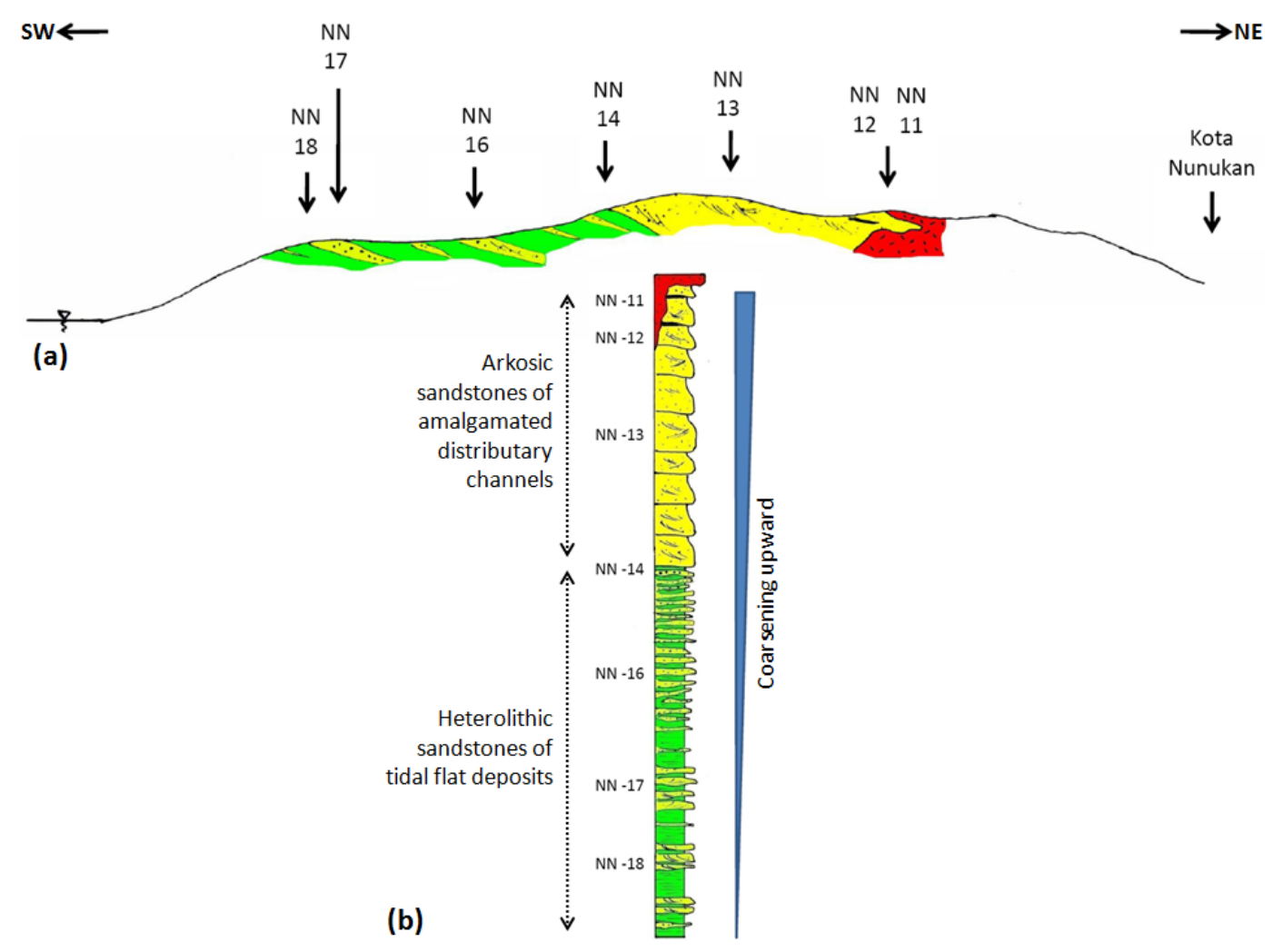

Figure 9: (a) Exploratory geological cross section of the western part of Nunukan Island; depicting coarsening-upward lithofacies trend of Tabul Formation (b), and their relation to the basalt intrusion.

with the main role of transpressional wrench of regional NW-SE major bounding strike-slip faults, i.e. Semporna, Maratua and Mangkalihat faults (Lentini and Darman, 1996; Rosary et al., 2014). Others apparently consent with deep thrust from west (Wight et al., 1992).

Those silisiclactic sequence of Tabul Formation intruded by basalt (Figure 9). On geological map (Hidayat et al., 1995), the basalt intrusion/volcanics expose in Kampung Baru (NE Nunukan) and Tanjung Batu (NW Nunukan). Asmoro et al. (2016) added three others basalt outcrops at the mid part of island, i.e. Mambunut, Sei Apok, and Panamas. However, as those three basalt outcrops encircled a topographic high, author proposes those basalts probably belong to one larger subcropped igneous body that dictated the local morphology, which in Figure 2 is represented by a half-ring of pink dashed-line.

The intrusion probably took place in PlioPleistocene (Hidayat et al., 1995), but whether they have been involved in the Ahus Arch formation or separated yet synchronous event. Asmoro et al. (2016) suggested those basalt volca- noes were much older, that they were consecutively erupted and built the Nunukan Island contemporaneously with deposition of Tabul Formation. There are no petrogenetic analysis on those Nunukan basalts, hence it is difficult to interpret their geodynamic setting. As with other Plio-Pleistocene basaltic rocks on Semporna Peninsula, they are probably associated with subduction-related origin (Wang et al., 2016), either the Celebes Sea Plate as subducted slab (Chiang, 2002; Hidayati et al., 2007), the Sulu Sea Plate as subducted slab (Castillo et al., 2007), or the on-going subducted Dangerous Ground Continental Plate (Wang et al., 2016).

Different interpretation was given by Macpherson et al. (2010) based on geochemical signatures and tomographic study, they proposed that the Plio-Pleistocene magmatism on Semporna Peninsula resulted from OIB (ocean island basalt)-like upwelling into lithospheric thin spots. Geodynamically, this interpretation requires a thinning transitional crust underlying the region, which have also been proposed by Hidayati et al. (2007) and Salahuddin et al. (2011). 
However, the role of Plio-Pleistocene magmatism with the arch formation is poorly understood and no research have address this matter yet. The proposed geological map depicts the main igneous body lies in the mid of Nunukan Island, alongside with the crestal line of Nunukan Anticline (Figure 2). Then again, the presence of anticlinal structures were also indistinctly defined on the surface, a condition that was expected as the island sits on top of Arch structure. From the outcrop NN.12, the Tabul Formation was deformed by an E-W faults resulting from NE-SW compressional stress, which have been inferred to be derived from the sinistral movement of Semporna Fault, the northern bounding structure whose supposed to be responsible for arches formation. As those Tabul outcrop and their faults were cut by basalt, it is highly possible if the magmatism occurred shortly after the faulting. At this point in time, it is quite remote to assume the diapiric magmatism had caused the arch formation. On regional geologic map of Hidayat et al. (1995), those Plio-Pleistocene igneous volcanics onshore mainland of North Kalimantan were randomly scattered and it appears that they do not fit to any structural trends.

\section{CONCLUding REMARKS}

The field geological observation from several key outcrops onshore of the Nunukan Island suggests that the island was mainly built by Neogene deposition of paleo-Simengaris Delta, i.e. the Late Miocene Tabul Formation and the Pliocene Tarakan Formation, to be later intruded by Plio-Pleistocene basalt volcanics.

The lower part of Tabul Formation was built by heterolithic sandstones deposited in tidal flats within an estuarine environment. Its coarsening upward succession suggests a sytem tract shifting, from the last stage of highstand to the initial phase of falling stage. The upper part of Tabul Formation was mainly composed of fine to medium grained arkosic sandstones, with abundant well-rounded lithic fragments, deposited in amalgamated channel structures. This succession was deposited during the initial phase of lowstand system tract, in distributary channels of upper delta plain, occasionally interupted by shales and lignite deposited in crevasse splays and flood plains.
The subsequent progradation of paleoSimengaris Delta during Pliocene have produced Tarakan conglomerates, unconformably deposited over the Tabul Formation. The Tabul and Tarakan formation underwent substansial erosion on Plio-Pleistocene tectonic inversion, almost stripped the Tarakan Formation out of the Nunukan Island. This Plio-Pleistocene inversion was triggered by the sinistral movement of NW-SE Semporna Fault, initiating the formation of NW-SE trending Ahus Arch, including Nunukan Anticline as its NW extension.

The occurrence of basalt volcanism on the Nunukan Island is thought to be contemporaneous with the arch formation, as suggested by field evidence in the outcrop NN.12. These basalts were also control the morphology of Nunukan Island, particularly the north section. However as these basalts also sporadically cropped out onshore North Kalimantan mainland, apparently their occurrences have no association with the tectonic inversion caused by regional wrenching.

\section{ACKNOWLEDGEMENTS}

Author expresses gratefulness to PT. Pertamina EP Asset 5 for inviting the fieldtrip in November 2014, particularly to Mr. Zeppy Irwanzah for arranging everything.

\section{REFERENCES}

Achmad, Z. and L. Samuel (1984) Stratigraphy and depositional cycles in the N.E. Kalimantan Basin, Proceedings Indonesian Petroleum Association 13th Annual Convention, pp. 109-120.

Akuanbatin, H., Th. Rosandi, and L. Samuel, (1984) Depositional environment of the hydrocarbon bearing Tabul, Santul and Tarakan formations at Bunyu Island, N.E. Kalimantan, Proceedings Indonesian Petroleum Association 13th Annual Convention, pp. 425-442.

Asmoro, P., S. Bronto, M. Effendi, I. Christiana, dan A. Zaennudin (2016) Gunung Api Purba Pulau Nunukan, Kabupaten Nunukan, Provinsi Kalimantan Utara, Prosiding Seminar Nasional Aplikasi Sains \& Teknologi (SNAST), pp. 70-84.

Castillo, P.R., S.J. Rigby, and R.U. Solidum (2007) Origin of high field strength element enrichment in volcanic arcs: geochemical evidence from the southern Sulu Arc, southern Philippines. Lithos 97, pp. 271-288. doi: 10.1016/j.lithos.2006.12.012.

Chiang, K.K. (2002) Geochemistry of the Cenozoic Igneous Rocks of Borneo and Tectonic Implica- 
tions. Unpublished PhD Thesis, University of London, $364 \mathrm{pp}$.

Hidayat, S., Amiruddin, and D. Satrianas (1995) Geological map of the Tarakan and Sebatik Sheet, Kalimantan, Geological Research and Development Centre, Bandung.

Hidayati, S., E. Guritno, A. Argenton, W. Ziza, and I. Del Campana (2007) Re-Visited Structural Framework of the Tarakan Sub-Basin Northeast Kalimantan - Indonesia, Proceedings Indonesian Petroleum Association 31st Annual Convention and Exhibition. IPA07-G-109, 18 pp.

Lentini, M.R. and H. Darman (1996) Aspects of the Neogene tectonic history and hydrocarbon geology of the Tarakan Basin, Proceedings Indonesian Petroleum Association 25th Silver Anniversary Convention, pp. 241-251.

Netherwood, R., and A. Wight (1992) StructurallyControlled, Linear Reefs in a Pliocene Delta-Front Setting, Tarakan Basin, Northeast Kalimantan. Carbonate Rocks and Reservoirs of Indonesia: A Core Workshop, $37 \mathrm{pp}$.

Noon, S., J. Harrington, and H. Darman (2003) The Tarakan Basin, East Kalimantan: Proven Neogene Fluvio-Deltaic, Prospective Deep-Water and Paleogene Plays in A Regional Stratigraphic Context, Proceedings Indonesian Petroleum Association 29th Annual Convention and Exhibition. IPA03-G-136, 14 pp.
Rosary, D, A.B. Nicaksana, J.K. Wilkinson (2014) A Correlation of Climate Stratigraphy with Biostratigraphy to Confirm Stratigraphic Units in the Sebatik Area. Proceedings Indonesian Petroleum Association 38th Annual Convention and Exhibition. IPA14-G-258., 17 pp.

Salahuddin, A. Setianto, R. Avianto, and J. Sukanto (2011) Geological Evolution of the Berau subBasin, East Kalimantan: A New Interpretation from Remote Sensing Analysis. Prosiding Abstraksi Lokakarya Integrasi Informasi dan Data serta Pengembangan Konsep Geosains dalam Rangka Optimalisasi Potensi Sumberdaya Hidrokarbon Cekungan-Cekungan Kalimantan, Balikpapan, 2 pp.

Shanley, K.W. and P.J. McCabe (1984) Perspectives on the sequence stratigraphy of continental strata, Am. Assoc. Petrol. Geol. Bull. 78, pp. 544-568.

Wang, P.C., S.Z. Li, L.L. Guo, S.H. Jiang, I.D. Somerville, S.J. Zhao, B.D. Zhu, J. Chen, L.M. Dai, Y.H. Suo, and B. Han (2016) Mesozoic and Cenozoic accretionary orogenic processes in Borneo and their mechanisms, Geol. J. 51(S1): 464-489.

Wight, A.W.R., L.H. Hare, and J.R. Reynolds (1993) Tarakan Basin, NE Kalimantan, Indonesia: a century of exploration and future potential, Geol. Soc. Malaysia, Bulletin 33, pp. 263-288. 